\title{
The use of volatile compounds as an alternative method in pepper breeding (Capsicum baccatum var. pendulum)
}

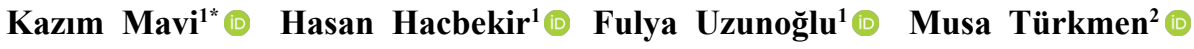 \\ ${ }^{1}$ Hatay Mustafa Kemal University, Faculty of Agriculture, Department of Horticulture, Hatay, Turkey. E-mail: kazimmavi@hotmail.com. \\ "Corresponding autor. \\ ${ }^{2}$ Hatay Mustafa Kemal University, Faculty of Agriculture, Department of Field Crops, Hatay, Turkey.
}

ABSTRACT: The aim of this study is to determine some fruit characteristics of 19 different lines hybridized by previous regular studies. These lines were examined in order to determine the differences among volatile components and reveal the differences in comparison with the parents. Plant height (cm), fruit weight $(\mathrm{g})$, fruit width $(\mathrm{mm})$, fruit length ( $\mathrm{mm})$, fruit flesh thickness (mm), pungency, immature fruit color and mature fruit color were determined of parents and F4 lines. As a result, a wide range of variations were determined between lines and parents in terms of all parameters apart from pungency. Especially in terms of volatile components, it has been found that some active substances are found only in the father and white genotype (Fenchol, spathulenol and geranyl acetate), some of them only in the mother and orange genotype ( $\alpha$-terpineol, dihexyl azelate and 2-hexadecanol). It was concluded that volatile compounds of the species can be used as a marker for breeding studies.

Key words: chili, hybridization, pepper breeding, volatile components.

O uso de compostos voláteis como método alternativo no melhoramento da pimenta (Capsicum baccatum var. pendulum)

RESUMO: O objetivo deste estudo é determinar algumas características dos frutos de 19 linhagens diferentes hibridizadas por estudos regulares anteriores. Essas linhas foram examinadas a fim de determinar as diferenças entre os componentes voláteis e revelar as diferenças em comparação com os pais. Altura da planta (cm), peso do fruto (g), largura do fruto (mm), comprimento do fruto (mm), espessura da polpa do fruto (mm), pungência, cor do fruto imaturo e cor do fruto maduro foram determinados dos pais e das linhas F4. Como resultado, uma ampla gama de variações foi determinada entre as linhas e os pais em termos de todos os parâmetros, exceto a pungência. Especialmente em termos de componentes voláteis, verificou-se que algumas substâncias ativas são encontradas apenas no genótipo pai e branco (Fenchol, espatulenol e acetato de geranila), algumas delas apenas no genótipo mãe e laranja ( $\alpha$-terpineol, azelato de dihexila e 2-hexadecanol). Concluiu-se que compostos voláteis da espécie podem ser usados como marcadores para estudos de melhoramento.

Palavras-chave: pimenta, hibridização, melhoramento de pimenta, componentes voláteis.

\section{INTRODUCTION}

As a widely consumed popular vegetable in the world and also in our country, pepper is rich in vitamins and minerals and beneficial for human nutrition. Capsicum types are consumed single or combined with other flavoring products to be fresh, canned, pickled or dried. Annually, 36771482 tons of fresh peppers are produced in 1990423 hectares in the world. Turkey is one of the leading countries with 2554974 tons of production with 91973 ha in the world (FAO, 2018).

The Capsicum genera(ESHBAUGH, 2012; CARRIZO GARCIA et al., 2016) consist of 43 species with 5 of them newly discovered species (BARBOZA et al., 2019; BARBOZA et al., 2020; MAVI, 2020). Among these species, 5 of them, $C$. annuum L., $C$. frutescens L., C. baccatum L., C. chinense Jacq. and C. pubescens Ruiz \& Pav., are cultured. Although the genetic variation within the Capsicum annuum species is wide, this wide variation causes susceptibility to some diseases such as root rot (P. capsici) and anthracnose (Colletotrichum acutatum, C. capsici etc.). Pepper varieties have always been in the interest of breeders due to differences in their resistance to biotic and abiotic stress conditions. Particularly exotic pepper varieties being not studied widely have been of interest to breeders in recent years. 
Cultured varieties of $C$. baccatum species were developed from $C$. baccatum var. pendulum subtype. Some genotypes belonging to the $C$. baccatum species have been reported having 53.42 to $54.11 \mathrm{mg} \beta$-carotene and 2.71 to $3.03 \mathrm{mmol}$ of antioxidant compounds in $100 \mathrm{~g}$ fresh fruits (ACUNHA et al., 2017). It has been determined that total phenolic content of $C$. baccatum fruit parts have similar or higher than other Capsicum species. Epitanthiol, 3-isobutyl-2-methoxypyrazine and various phenols (eg guaiacol) and terpenoids (eg $\alpha$-pinene, 1,8-cineol, linalool) produce the aroma of some 3-methyl-2-butyl esters of $C$. baccatum fruits (KOLLMANNSBERGER et al., 2011). The result of the analysis performed on fresh fruits reveals that the total flavonoids of the Aji Angelo variety of Capsicum baccatum were 3 times higher than the varieties of other species (LOIZZO et al., 2015) and varied among genotypes (GOMES et al., 2019). It has also been used in interspecific crosses in order to pass these aromatic compounds in its structure to varieties belonging to the $C$. annuum species (EGGINK et al. 2014). It has also been reported that Capsicum baccatum contains potential antioxidant and anti-inflammatory compounds that can be tested as drug candidates against oxidative and inflammation-related pathological processes in medical chemistry studies (WAHYUNI et al., 2011).

Although there is a wide variety of species, especially in South American countries (CARDOSO et al., 2018), most of the varieties grown commercially in Turkey, which is an important pepper production center is based on the $C$. annuum species. The use of other pepper species in our country is limited to their use as hobby ornaments and for breeding studies by breeding companies. In recent years, genotypes of the C. baccatum species have started to be sold in the markets. However, there is no such varieties have been developed in Turkey. A breeding program has been initiated in order to popularize the unique taste of this species in our country, to highlight the superior characteristics of the species, and to develop its diversity (MAVI, 2015). As a result of the breeding program planned in line with these objectives, this study was carried out in order to develop varieties with different characteristics (color, aroma, pungency, etc.) among the chemical components of this type of fruit. The aim of the study is to determine some fruit characteristics of 19 different lines selected from individuals which were hybridized with regular studies before the project and brought to the F4 stage and to reveal the differences between them in comparison with the parents. It is also to determine how volatile compounds change in parents and selected genotypes in relation to fruit colors.

\section{MATERIALS AND METHODS}

Two pure line mother (cv. MKÜ-92, q, mature fruit yellow) and father (cv. MKÜ-19, 0 , mature fruit dark red) belonged to Hatay Mustafa Kemal University Faculty of Agriculture Horticulture genetic collection were used as parents (Figure 1). These two pure lines were included in the breeding program due to the different aroma, colors and shapes of the mature fruit and both being efficient lines. They were preferred because the lines being phenotypically different from each other would cause a wider variation to be obtained.

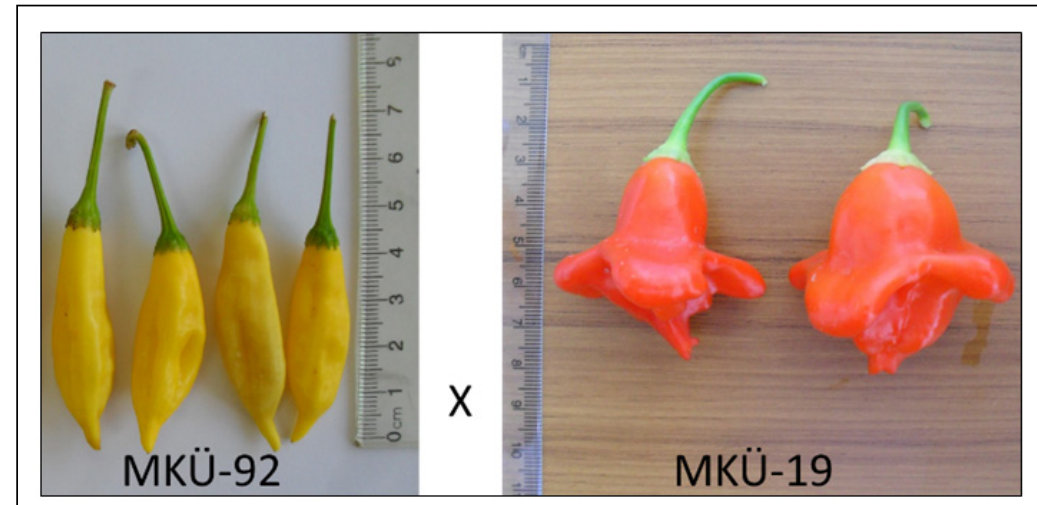

Figure 1 - Difference in shape and color of mature fruit of mother and father parents. 
Since the parents were pure lines, all obtained plants in the F1 phase were alike; with red colored mature fruits. As a result of the selfing of F1 individuals, a wide variation was obtained in terms of fruit color and shape in F2 and F3 stages. Examples of color and shape differences in mature fruits of F3 individuals are shown in figure 2. 19 lines with different phenotypic characteristics selected by monopoly selection among 500 F4 individuals obtained by in bringing F3 individuals constituted the plant material of this study.

F4 lines were grown in a pot cultivation in an unheated greenhouse. Perlite peat mixture was used as the growing medium. The seedlings were planted in August 2019. Cultural processes such as fertilization, irrigation and spraying were applied regularly. During the cultivation, the temperature inside the greenhouse varied between a minimum of $-2{ }^{\circ} \mathrm{C}$ and a maximum of $30{ }^{\circ} \mathrm{C}$.

Plant height, unmature fruit color, mature fruit color, pungency (sensory taste), fruit weight, fruit length, fruit width and fruit thickness were examined separately for each line (MAVI, 2015). Data on fruit characteristics were obtained by taking the average of 10 fruits in 3 repetitions. Unmature fruit color and mature fruit color were visually classified as reported in the pepper identification guideline (IPGRI, 1995).

GS-MS chromatography was performed in order to determine the differences in essential component in these genotypes based on the four basic colors in mature fruits. Samples of white, orange, yellow and red mature fruits were dried in the oven at $50{ }^{\circ} \mathrm{C}$ for 48 hours. Volatile components were obtained by distilling $50 \mathrm{~g}$ of dry sample of each color with water. The determination of essential oil components was carried out under the following conditions with Thermo Scientific ISQ Single Quadrupole model Gas Chromatograph device. TR-FAME MS model, 5\% Phenyl Polysilphenylene-siloxane, $0.25 \mathrm{~mm}$ inner diameter x $60 \mathrm{~m}$ length, $0.25 \mu \mathrm{m}$ film thickness column was used. Helium (99.9\%) was used as the carrier gas at a flow rate of $1 \mathrm{~mL} / \mathrm{min}$. Ionization 22 energy was set at $70 \mathrm{eV}$, mass range m / z 1.2-1200 amu. Scan Mode was used for data collection. The MS transfer line temperature was $250{ }^{\circ} \mathrm{C}$, the MS ionization temperature was 220 ${ }^{\circ} \mathrm{C}$, the injection port temperature was $220^{\circ} \mathrm{C}$, the column temperature was $50^{\circ} \mathrm{C}$ at the beginning and it was increased to $220{ }^{\circ} \mathrm{C}$ with a temperature increase rate of $3{ }^{\circ} \mathrm{C} / \mathrm{min}$. The structure of each compound was defined using the Xcalibur program and mass spectra (Wiley 9 library) (TURKMEN et al., 2016).

Analysis of variance was performed using the SPSS package program for statistical comparison of the data obtained. Lines with statistical differences between their averages were compared by subjecting them to Duncan test at 5\% significance level. Dendograms in figure 3 showing the similarities and differences of genotypes with each other were created using Hierarchical Cluster Analysis (Hierarchical Cluster Analysis) and Ward's method in the SPSS package program.

\section{RESULTS AND DISCUSSION}

Average plant height of the selected genotypes varied between $48 \mathrm{~cm}$ and $115 \mathrm{~cm}$. The

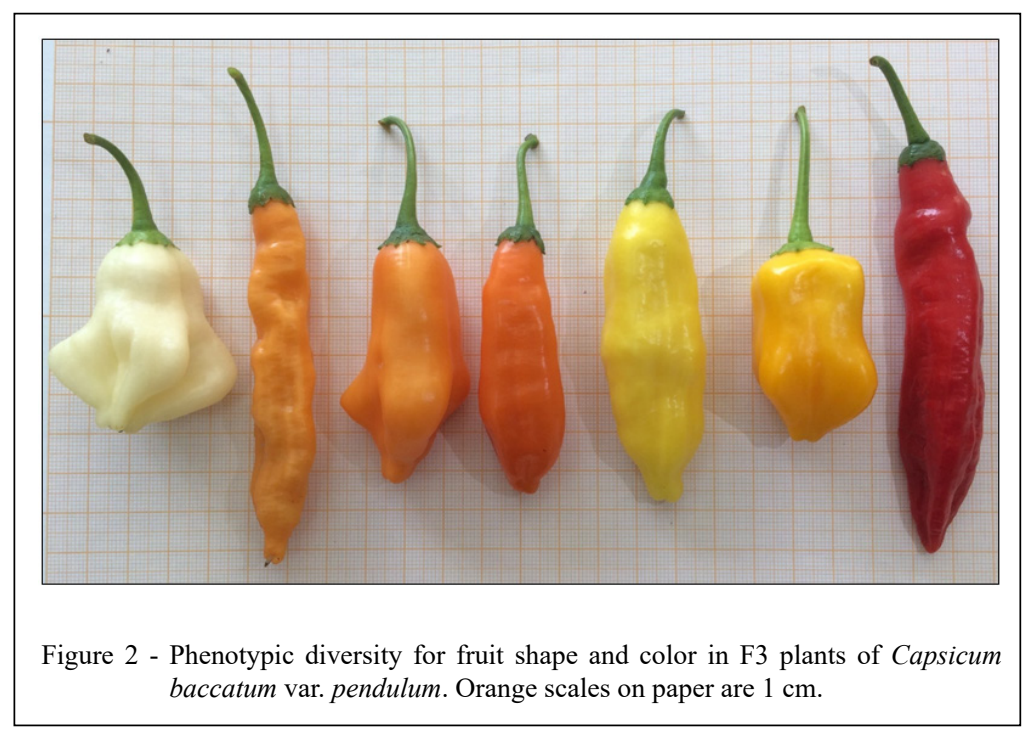

Ciência Rural, v.51, n.12, 2021. 


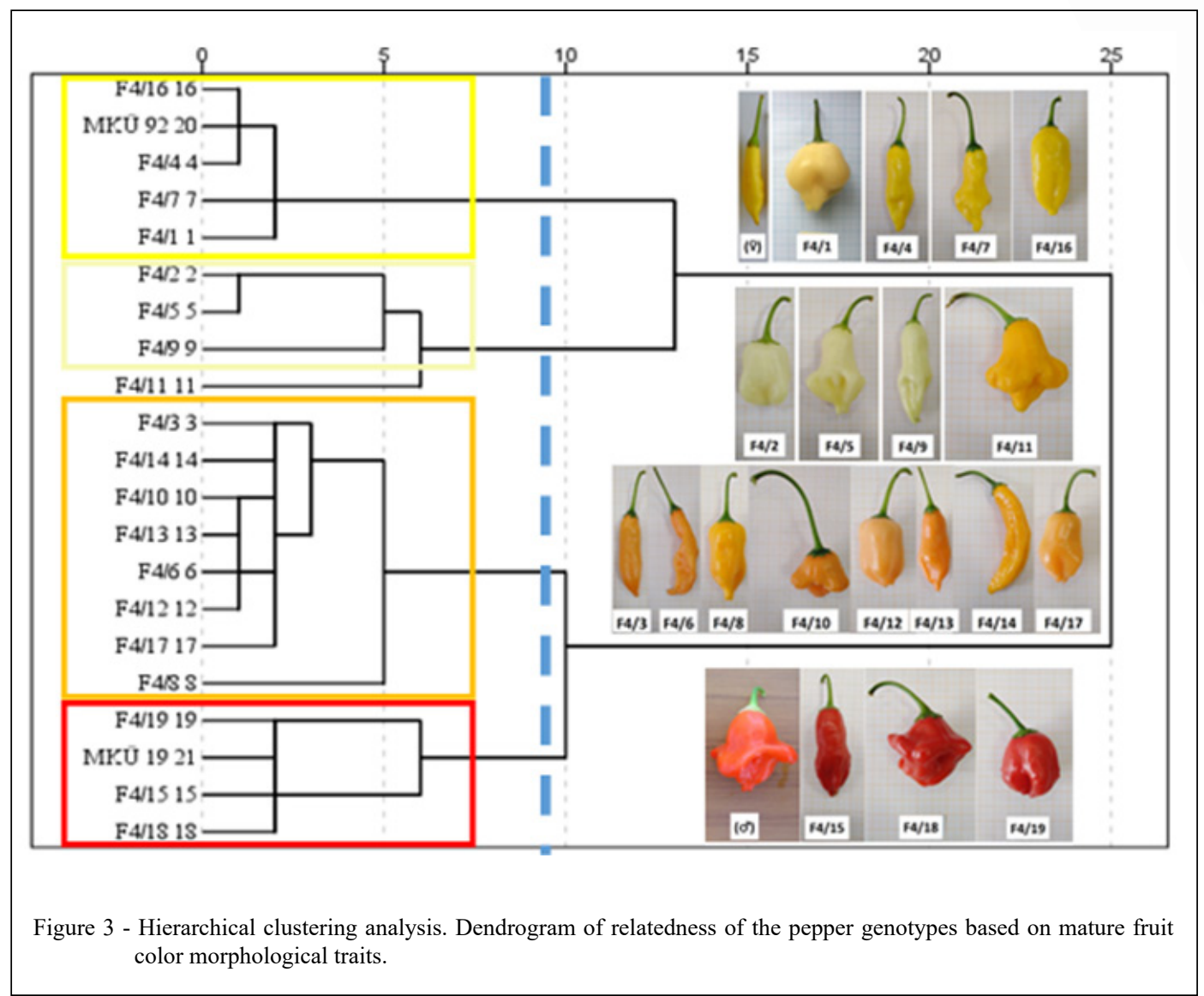

mother and father parents, on the other hand, had a plant height of 55 and $88 \mathrm{~cm}$, respectively. F4 / 19 is shorter than both of the parents, while the plant height of five genotypes is longer than $100 \mathrm{~cm}$. The genotypes selected in terms of immature fruit colors had different colors. On the other hand, mature fruit colors had variation in genotypes. As a result of the hybridization of yellow fruit colored mother and dark red father parents, white (F4 / 2, F4 / 5, F4 / 9,), yellow (F4 / 1, F4 / 4, F4 / 7, F4 / 16,), dark yellow (F4 / 11), light orange (F4 / 8, F4 / 17), orange (F4 / 6, F4 / 10, F4 / 12, F4 / 13), dark orange (F4 / 3, F4 / 14), Red (F4 / 15, F4 / 18), and dark red (F4 / 19) lines with mature fruit color were obtained. As a result of the sensory test, it was found that the whole genotype and parents were pungent (Table 1).

The genotype with the heaviest fruits was determined as F4 / 18 (19.06 g) and the genotype with the lightest fruits was determined as F4 / 3 (4.69 g). In the genotypes with upright fruit position, it was found that the fruits took a pendulous position with the increase in fruit weight. Fruit weight of 16 of the selected genotypes remained between parental averages. Genotypes had lengths varying between $36.28 \mathrm{~mm}$ and $81.16 \mathrm{~mm}$ in terms of fruit length. Long genotypes received these characteristics from mother parents, short genotypes from father parents. Fruit widths varied from $17.89 \mathrm{~mm}$ to $55.68 \mathrm{~mm}$. In terms of this feature, it can be said that narrow-fruit genotypes resemble the mother, and large fruits resemble the father. While fruit thickness was found to be thinner than the parental average in all four genotypes, it was not found higher than the parental average in any genotype (Table 2).

As a result of the hierarchical dendogram drawn considering the mature fruit colors, four different groups were formed, while the mother and father parents were in different groups. Red and yellow fruit genotypes were collected in two different groups, while fruits with white and orange tones were in the 2 nd and 3 rd groups. For example, genotypes coded F4 / 1, F4 / 5, F4 / 10 and F4 / 11, which are similar to the father parent in terms of fruit shape, 
Table 1 - Plant height, immature fruit color, mature fruit color and pungency (sensory) of Baccatum genotypes.

\begin{tabular}{|c|c|c|c|c|}
\hline Lines & Plant height $(\mathrm{cm})$ & Unmature fruit colour & Mature fruit colour & Pungency \\
\hline MKÜ-92 (Mother) & 55 & Green & Yellow & Hot \\
\hline MKÜ-19 (Father) & 88 & Dark green & Dark red & Hot \\
\hline $\mathrm{F} 4 / 1$ & 92 & Light green & Yellow & Hot \\
\hline $\mathrm{F} 4 / 2$ & 95 & Very light green & White & Hot \\
\hline $\mathrm{F} 4 / 3$ & 70 & Green & Dark orange & Hot \\
\hline $\mathrm{F} 4 / 4$ & 105 & Green & Yellow & Hot \\
\hline $\mathrm{F} 4 / 5$ & 90 & Very light yellow & White & Hot \\
\hline $\mathrm{F} 4 / 6$ & 96 & Green & Orange & Hot \\
\hline $\mathrm{F} 4 / 7$ & 91 & Dark green & Yellow & Hot \\
\hline $\mathrm{F} 4 / 8$ & 88 & Light green & Light orange & Hot \\
\hline $\mathrm{F} 4 / 9$ & 70 & Greenish white & White & Hot \\
\hline $\mathrm{F} 4 / 10$ & 115 & Dark green & Orange & Hot \\
\hline $\mathrm{F} 4 / 11$ & 105 & Light yellow & Dark yellow & Hot \\
\hline $\mathrm{F} 4 / 12$ & 80 & Green & Orange & Hot \\
\hline $\mathrm{F} 4 / 13$ & 112 & Dark green & Orange & Hot \\
\hline $\mathrm{F} 4 / 14$ & 75 & Dark Green & Dark orange & Hot \\
\hline $\mathrm{F} 4 / 15$ & 85 & Greenish white & Red & Hot \\
\hline $\mathrm{F} 4 / 16$ & 86 & Green & Yellow & Hot \\
\hline $\mathrm{F} 4 / 17$ & 113 & Green & Light orange & Hot \\
\hline $\mathrm{F} 4 / 18$ & 69 & Light green & Red & Hot \\
\hline $\mathrm{F} 4 / 19$ & 48 & Green & Dark red & Hot \\
\hline
\end{tabular}

were included in different groups because they were in different colors from the father parent (Figure 3).

It has been determined that the chemical compositions of the lines of different colors differ in terms of basic components. The total number of compounds determined in four different colored fruits was 95 (Figure 4). In the distribution of these compounds according to colors, 46 different compounds in orange, 42 in yellow, 37 in red and 27 in white were determined (data not shown). Among the colors obtained as a result of hybridization of mother and father parents, a higher compound was found in orange than parents, while a lower number of compounds was determined in white colored ones.

The distribution of the five most common compounds in proportion according to fruit colors was presented in figure 5. The most abundant compound in white, red and yellow fruits was Linalool $(53.7 \%, 38.7 \%$ and $23.9 \%$, respectively). In orange colored ones, hexyl hexanoate (20.4\%) was detected the most, followed by Linalool with $10.8 \%$. While the amount of linalool was higher in white genotypes than parents, it was lower in orange genotypes (Figure 5).

Studies have reported that genotypes with long plant height have higher yields (REGO et al., 2010). In our study, studies on the yield-related properties of plants taller than the parents, disease resistance and biochemical properties of the lines shorter than the parents continue.

As a result of the hybridization of yellow fruit colored mother and dark red father parents, white (F4 / 2, F4 / 5, F4 / 9,), yellow (F4 / 1, F4 / 4, F4 / 7, F4 / 16,), dark yellow (F4 / 11), light orange (F4 / 8, F4 / 17), orange (F4 / 6, F4 / 10, F4 / 12, F4 / 13), dark orange (F4 / 3, F4 / 14), red (F4 / 15, F4 / 18), and dark red (F4 / 19) lines with mature fruit color were obtained. Studies have reported differences in mature fruit colors in genotypes obtained by selection (REGO et al., 2010; CARDOSO et al., 2018). However, a line obtained by crossing mature fruits with white color has not been reported before.

In studies conducted, it was found that the average fruit weight of 116 genotypes in the Brazilian gene bank belonging to baccatum species was $8 \mathrm{~g}$, the average fruit length was $5 \mathrm{~cm}$, the average fruit width was $2.5 \mathrm{~cm}$ and the average fruit thickness was $2 \mathrm{~mm}$ (CARDOSO et al., 2018). When evaluated in terms of fruit weight and wall thickness, some of the F4 lines obtained in our study were below these averages (F4 / 3, F4 / 4 and F4 / 14), some similar (F4 / 6), some higher (F4 / 1, F4 / 5 and F4 / 18).

Ciência Rural, v.51, n.12, 2021. 
Table 2 - Changes fruit weight, fruit length, fruit width and fruit flesh thickness in Baccatum lines.

\begin{tabular}{|c|c|c|c|c|}
\hline Lines & Fruit weight (g) & Fruit length (mm) & Fruit width $(\mathrm{mm})$ & Fruit flesh thickness $(\mathrm{mm})$ \\
\hline MKÜ-92 & 7.75 ef $^{*}$ & $70.67 \mathrm{bc}$ & $17.78 \mathrm{i}$ & $2.03 \mathrm{gh}$ \\
\hline MKÜ-19 & $17.80 \mathrm{a}$ & $44.67 \mathrm{gh}$ & $50.35 \mathrm{~b}$ & $3.35 \mathrm{a}$ \\
\hline $\mathrm{F} 4 / 1$ & $14.48 \mathrm{~b}$ & $54.45 \mathrm{f}$ & $32.30 \mathrm{def}$ & $3.20 \mathrm{ab}$ \\
\hline $\mathrm{F} 4 / 2$ & $9.61 \mathrm{de}$ & $37.68 \mathrm{hi}$ & $31.42 \mathrm{def}$ & $2.84 \mathrm{bcd}$ \\
\hline $\mathrm{F} 4 / 3$ & $4.69 \mathrm{~g}$ & $62.24 \mathrm{de}$ & $17.89 \mathrm{i}$ & $1.53 \mathrm{I}$ \\
\hline $\mathrm{F} 4 / 4$ & $6.05 \mathrm{fg}$ & $61.82 \mathrm{de}$ & $21.75 \mathrm{hi}$ & 1.65 hi \\
\hline $\mathrm{F} 4 / 5$ & $12.22 \mathrm{c}$ & $53.65 \mathrm{f}$ & $38.36 \mathrm{c}$ & 2.49 cdef \\
\hline $\mathrm{F} 4 / 6$ & $7.96 \mathrm{ef}$ & $79.04 \mathrm{a}$ & $27.43 \mathrm{fg}$ & $1.69 \mathrm{hi}$ \\
\hline $\mathrm{F} 4 / 7$ & $9.75 \mathrm{de}$ & $74.19 \mathrm{ab}$ & $29.27 \mathrm{efg}$ & $1.65 \mathrm{hi}$ \\
\hline $\mathrm{F} 4 / 8$ & $11.40 \mathrm{~cd}$ & $56.60 \mathrm{ef}$ & $27.86 \mathrm{fg}$ & $2.51 \mathrm{cdef}$ \\
\hline F4/9 & $11.47 \mathrm{~cd}$ & $81.16 \mathrm{a}$ & $28.53 \mathrm{efg}$ & $2.13 \mathrm{fg}$ \\
\hline $\mathrm{F} 4 / 10$ & $9.62 \mathrm{de}$ & $41.10 \mathrm{hi}$ & $35.00 \mathrm{~cd}$ & $2.94 \mathrm{abc}$ \\
\hline $\mathrm{F} 4 / 11$ & $8.96 \mathrm{e}$ & 43.63 ghi & $35.11 \mathrm{~cd}$ & $2.27 \mathrm{efg}$ \\
\hline $\mathrm{F} 4 / 12$ & $8.76 \mathrm{e}$ & $37.08 \mathrm{hi}$ & $29.25 \mathrm{efg}$ & 2.72 cde \\
\hline $\mathrm{F} 4 / 13$ & $12.16 \mathrm{c}$ & $65.80 \mathrm{~cd}$ & $33.26 \mathrm{de}$ & $2.27 \mathrm{efg}$ \\
\hline $\mathrm{F} 4 / 14$ & 7.91 ef & $79.84 \mathrm{a}$ & $18.77 \mathrm{i}$ & $2.15 \mathrm{fg}$ \\
\hline $\mathrm{F} 4 / 15$ & $12.26 \mathrm{c}$ & $62.33 \mathrm{~cd}$ & $29.11 \mathrm{efg}$ & 2.49 cdef \\
\hline $\mathrm{F} 4 / 16$ & $9.78 \mathrm{de}$ & $53.07 \mathrm{ef}$ & $24.89 \mathrm{gh}$ & $2.40 \mathrm{defg}$ \\
\hline F4/17 & $13.47 \mathrm{~b}$ & $48.95 \mathrm{fg}$ & $31.20 \mathrm{def}$ & $2.94 \mathrm{abc}$ \\
\hline F4/18 & $19.06 \mathrm{a}$ & 43.56 ghi & $55.68 \mathrm{a}$ & $2.58 \mathrm{cdef}$ \\
\hline F4/19 & $9.41 \mathrm{de}$ & $36.28 \mathrm{i}$ & $30.09 \mathrm{def}$ & $2.55 \mathrm{cdef}$ \\
\hline
\end{tabular}

*The difference between the means indicated by different letters in the same column is statistically significant $(\mathrm{P}<0.05)$.

It has been determined that there is a positive linear relationship between fruit weight and wall thickness in $C$. chinense species and it has been reported that wall thickness is an important criterion for the selection of varieties suitable for fresh consumption. Thicker fleshy fruits are more resistant to post-harvest processing and injury during transportation (LANNES et al., 2007). In Capsicum

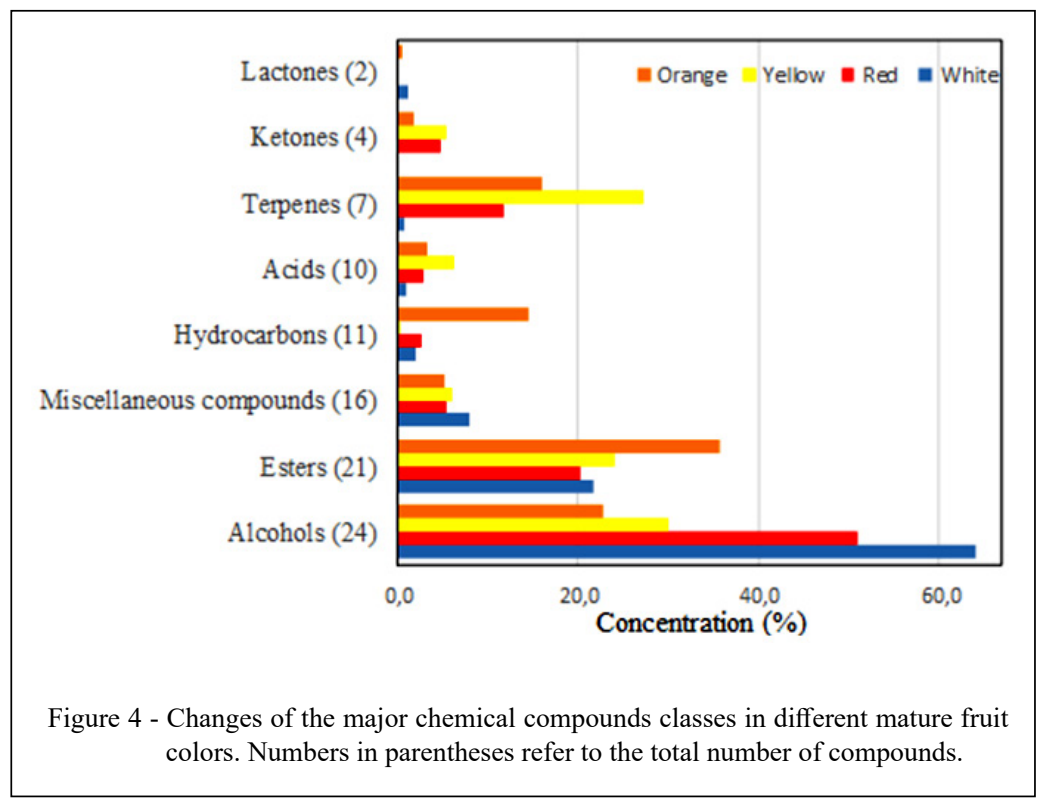

Ciência Rural, v.51, n.12, 2021. 
baccatum genotypes, it has been determined that those with a wall thickness greater than $3 \mathrm{~mm}$ have a longer shelf life (REGO et al., 2011). Therefore, the F4 / 1 coded genotype was found to be used in later breeding studies in terms of wall thickness $(3.20 \mathrm{~mm})$.

The importance of aroma compounds in breeding is increasing day by day. In pepper breeding, it is gaining importance every day in terms of promoting anti-carcinogenic substances that are beneficial for human health (WAHYUNI et al., 2011).

In studies conducted on pepper, it has been determined that there are more than 200 different compounds classified as terpenes, hydrocarbons, alcohols, aldehydes, ketones, acids, esters, lactones and phenolics in genotypes belonging to different species (ANTONIO et al., 2018). With the method in this study, a total of 95 components were detected in four different fruit-colored Capsicum baccatum. var pendulum genotypes. Although the white genotype has the fewest compounds with 27 compounds, it was determined that it contains a higher proportion of linalool, linalyl acetate, caryophyllene oxide and spathulenol components than other genotypes. The scarcity of components in white genotype is thought to be due to the lack of active ingredients used in color synthesis. It was reported by PINO et al. (2007) that the components differ according to the color of the fruit in the genotypes of $C$. chinense species with different fruit colors. Unlike this study, it was reported that red fruit genotypes contain high amounts of hydrocarbons, which are generally associated with the biosynthesis of capsaicin and the degradation of carotenoids, while orange fruits contain high amounts of esters (PINO et al., 2007). This may be due to the different types used in these studies.

It is reported that Linalool gives the fruit a citrus like, fruity and floral aroma (XIAO et al., 2010). It has also been reported that linalool and hexyl hexanoate are found in $C$. baccatum species but not in $C$. chinense and $C$. pubescens. Fenchol is a component with a pungent, lime-like flavor, found only in white and red fruits.

\section{CONCLUSION}

As a result, it was determined that the lines selected in terms of fruit characteristics and chemical components have very different characteristics from the parents. Especially in terms of volatile components, it has been found that some active substances are found only in the father and white genotype (Fenchol, spathulenol and geranyl acetate),

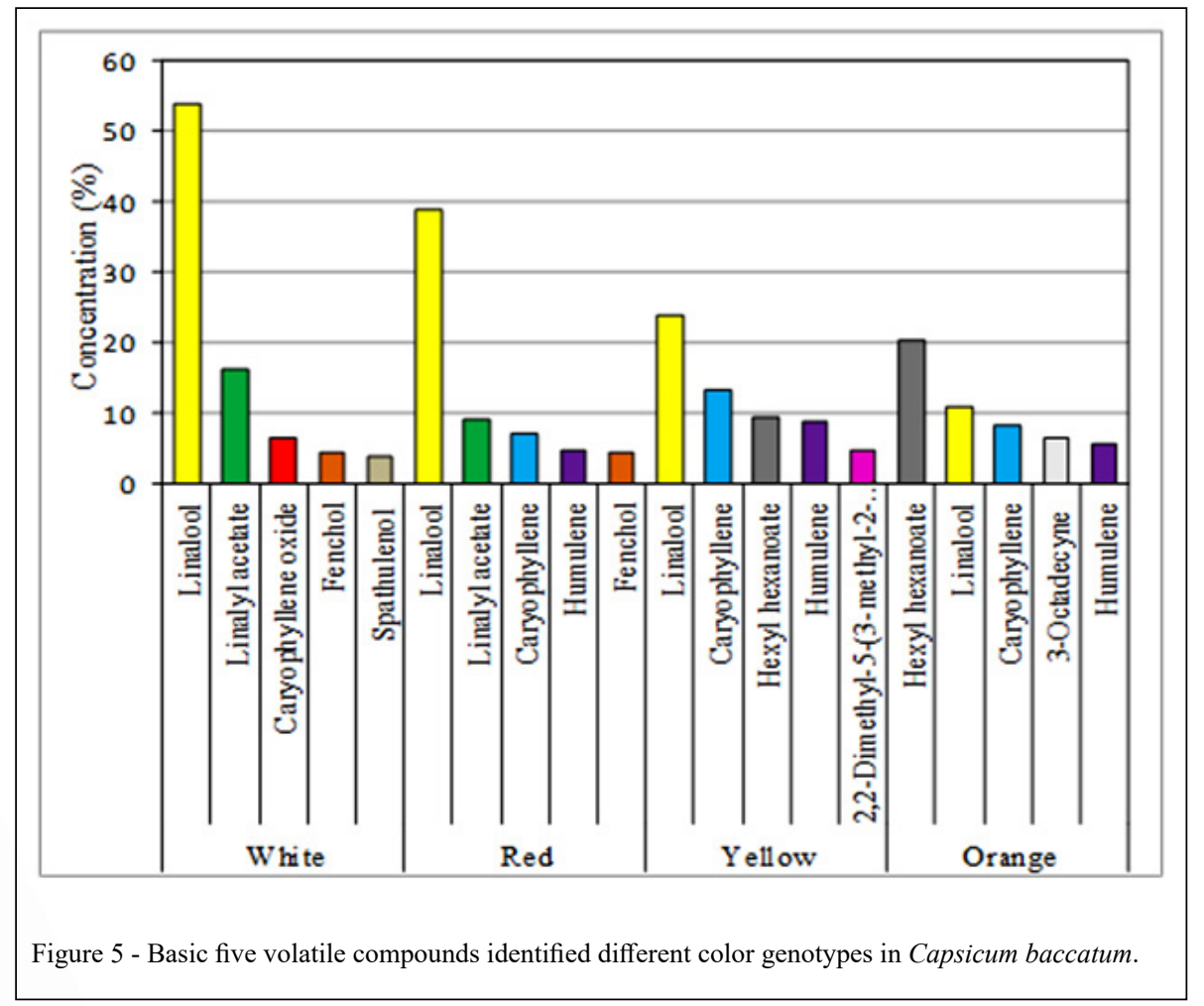

Ciência Rural, v.51, n.12, 2021. 
some of them only in the mother and orange genotype ( $\alpha$-terpineol, dihexyl azelate and 2-hexadecanol). These substances are thought to be considered as chemical markers in future studies. The use of genetically different parents is used to cause a wide range of genetic variation in subsequent generations due to the high heterozygous effect. Since the parents used in this study are phenotypically different from each other, a wide variation has been created with this breeding program. Each genotypes in this variation can be used in breeding programs for the characteristics aimed to be developed in terms of fruit characteristics and chemical content.

\section{ACKNOWLEDGEMENTS}

The study was partial funded by Hatay Mustafa Kemal University and TAGEM.

\section{DECLARATION OF CONFLICT OF INTEREST}

The authors declare no conflict of interest. The founding sponsors had no role in the design of the study; in the collection, analyses, or interpretation of data; in the writing of the manuscript, and in the decision to publish the results.

\section{AUTHORS' CONTRIBUTIONS}

All authors contributed equally for the conception and writing of the manuscript. All authors critically revised the manuscript and approved of the final version.

\section{REFERENCES}

ACUNHA, T. D. S. et al. Bioactive compound variability in a Brazilian capsicum pepper collection. Crop Science, v.57, p.1-13, 2017. Available from: $<$ https://doi.org/10.2135/cropsci2016.08.0701>. Accessed: Dec. 08, 2020. doi: 10.2135/cropsci2016.08.0701.

ANTONIO, A. S. et al. The genus Capsicum: a phytochemical review of bioactive secondary metabolites. RSC Advances, v.8, p.25767-25784, 2018. Available from: <https://doi.org/10.1039/ C8RA02067A>. Accessed: Dec. 08, 2020. doi: 10.1039/ C8RA02067A.

BARBOZA, G. E. et al. Capsicum carassense (Solanaceae), a new species from the Brazilian Atlantic Forest. PhytoKeys, v.140, p.125-138, 2020. Available from: <https://doi.org/10.3897/ phyookeys.140.47071>. Accessed: Dec. 08, 2020. doi: 10.3897/ phyookeys.140.47071.

BARBOZA, G. E. et al. Four new species of Capsicum (Solanaceae) from the tropical Andes and an update on the phylogeny of the genus. Plos One, v.14, n.1, p.e0209792, 2019. Available from: $<$ https://doi.org/10.1371/journal.pone.0209792>. Accessed: Dec. 08, 2020. doi: 10.1371/journal.pone.0209792.

CARDOSO, R. et al., Genetic variability in Brazilian Capsicum baccatum germplasm collection assessed by morphological fruit traits and AFLP markers. Plos One, v.13, n.5, p.e0196468. 1-15, 2018. Available from: <https://doi.org/10.1371/journal.pone.0196468>. Accessed: Dec. 08, 2020. doi: 10.1371/journal.pone.0196468.

CARRIZO GARCIA, C. et al. Phylogenetic relationships, diversification and expansion of chili peppers (Capsicum, Solanaceae). Annals of Botany, v.118, p.35-51, 2016. Available from: <https://doi.org/10.1093/aob/mcw079>. Accessed: Dec. 08, 2020. doi: 10.1093/aob/mcw079.

EGGINK, P. M. et al. Capturing flavors from Capsicum baccatum by introgression in sweet pepper. Theoretical and Applied Genetics, v.127, p.373-390, 2014. Available from: <https://doi. org/10.1007/s00122-013-2225-3>. Accessed: Dec. 08, 2020. doi: $10.1007 / \mathrm{s} 00122-013-2225-3$.

ESHBAugh, W. H. In: Peppers Botany, Production and Uses. Vincent M. Russo (Ed.). The taxonomy of the genus Capsicum, CAB International. p: 14-28, 2012.

FAO. Available from: <http://www.fao.org/faostat/en/\#data/QC>. 2018. Accessed: Oct. 22, 2020.

GOMES, G. P. et al. Characterization of biochemical compounds and antioxidant activity of "dedo-de-moça" chili pepper accessions. Horticultura Brasileira, v.37, p.429-436, 2019. Available from: $<$ https://doi.org/10.1007/s00122-013-2225-3>. Accessed: Dec. 08, 2020. doi: 10.1007/s00122-013-2225-3.

IPGRI. Descriptores for Capsicum (Capsicum spp.). International Plant Genetic Resources Institute, Rome, p.51, 1995. Available from: <https://www.bioversityinternational.org/fileadmin/_migrated/ uploads/tx_news/Descriptors_for_capsicum__Capsicum_ spp. 345.pdf $>$. Accessed: Dec. 08,2020 .

KOLLMANNSBERGER, H. et al. Volatile and capsaicinoid composition of ají (Capsicum baccatum) and rocoto (Capsicum pubescens), two Andean species of chile peppers. Journal of the Science Food and Agriculture, v.91, n.9, p.1598-1611, 2011. Available from: <https://doi.org/10.1002/jsfa.4354>. Accessed: Dec. 08, 2020. doi: 10.1002/jsfa.4354.

LANNES. S. D. et al. Growth and quality of Brazilian accessions of Capsicum chinense fruits. Scientia Horticulturae, v.112, p.266-270, 2007. Available from: <https://doi.org/10.1016/j. scienta.2006.12.029>. Accessed: Dec. 08, 2020. doi: 10.1016/j. scienta.2006.12.029

LOIZZO, M. R. et al. Evaluation of chemical profile and antioxidant activity of twenty cultivars from Capsicum annuum, Capsicum baccatum, Capsicum chacoense and Capsicum chinense: A comparison between fresh and processed peppers. LWT- Food Science and Technology, v.64, p.623-631, 2015. Available from: $<$ https://doi.org/10.1016/j.lwt.2015.06.042>. Accessed: Dec. 08, 2020. doi: 10.1016/j.lwt.2015.06.042.

MAVI, K. Ornamental pepper breeding program as potted plant in Turkey. Sixth International Scientific Agricultural Symposium Proceeding Book, p.602-607, 2015. Available from: $<$ http://agrosym.ues.rs.ba/agrosym/agrosym_2015/BOOK_OF_ PROCEEDINGS_2015.pdf $>$. Accessed: Dec. 08, 2020.

MAVI, K. Interspecific hybridization in pepper species. International Journal of Life Sciences and Biotechnology, v.3, n.3, p.386-406, 2020. Available from: <https://doi.org/10.38001/ijlsb.722036>. Accessed: Dec. 08, 2020. doi: 10.38001/ijlsb.722036.

Ciência Rural, v.51, n.12, 2021. 
PINO, J. et al. Characterization of total capsaicinoids, colour and volatile compounds of Habanero chilli pepper (Capsicum chinense Jacq.) cultivars grown in Yucatan. Food Chemistry, v.104, p.1682-1686, 2007. Available from: <https://doi.org/10.1016/j. foodchem.2006.12.067>. Accessed: Dec. 08, 2020. doi: 10.1016/j. foodchem.2006.12.067.

REGO, E. R. et al. Phenotypic diversity, correlation and importance of variables for fruit quality and yield traits in Brazilian peppers (Capsicum baccatum). Genetic Resources and Crop Evolution, v.58, p.909-918, 2010. Available from: <https://doi.org/10.1007/ s10722-010-9628-7>. Accessed: Dec. 08, 2020. doi: 10.1007/ s10722-010-9628-7.

TURKMEN, M. et al. Essential oil components of fresh coriander (Coriandrum sativum L.) herbs from different locations in Turkey. ICAMS 2016, 6 th International Conference on Advanced
Materials and Systems, p.305-308, 2016. Available from: <http:// icams.ro/icamsresurse/2016/proceedings/II_Biomaterials_19. pdf $>$. Accessed: Dec. 08, 2020.

WAHYUNI, Y. et al. Metabolite biodiversity in pepper (Capsicum) fruits of thirty-two diverse accessions: variation in health-related compounds and implications for breeding. Phytochemistry, v.72, p.1358-1370, 2011. Available from: <https://doi.org/10.1016/j. phytochem.2011.03.016>. Accessed: Dec. 08, 2020. doi: 10.1016/j. phytochem.2011.03.016.

XIAO, Z. B. et al. Comparison of volatile components in Chinese traditional pickled peppers using HS-SPME-GC-MS, GC-O and multivariate analysis. Natural Product Research, v.24, n.20, p.1939-1953, 2010. Available from: <https://doi.org/10. 1080/14786419.2010.506875>. Accessed: Dec. 08, 2020. doi: $10.1080 / 14786419.2010 .506875$. 